\title{
2 DE NOVEMBRO
}

Ulisses Diniz

Pernambuco

Estou no cemitério da saudade,

Em frente à cova do meu sonho morto;

Tristonho e só, num longo desconfôrto

Rezo, contrito, em plena soledade!

Pendida a fronte, sem achar confôrto

A não ser no silêncio que me invade,

Eu tenho o mesmo aspecto, na verdade,

Se é que posso dizer, de Jesus no Hôrto.

$E$ aos lânguidos repiques em surdina

De sinos, a aumentar a minha mágoa,

Vejo passar a procissão (que sina!)

Das visões dos meus sonhos malogrados,

Enquanto sinto os olhos rasos d'água

Neste saudoso dia de finados!... 